\title{
Impact of Coronavirus Disease-19 Lockdown on Egyptian Children and Adolescents: Dietary Pattern Changes Health Risk
}

\author{
Shaimaa A. Hashem*, Amira S. El Refay, Hend H. Mostafa, Iman H. Kamel, Lobna S. Sherif \\ Department of Child Health, National Research Centre, Dokki, Giza, Egypt
}

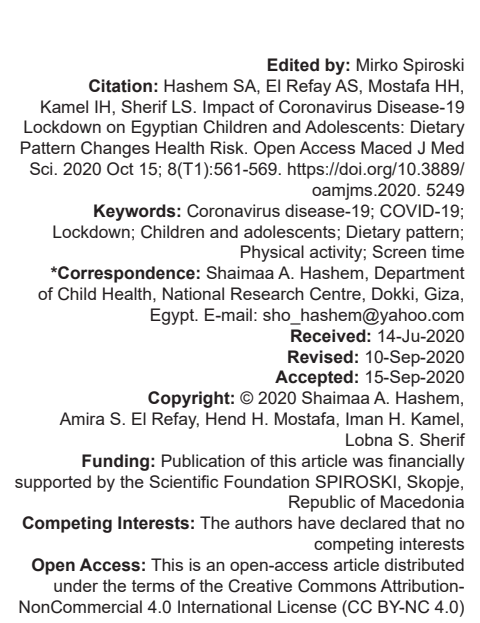

\section{Introduction}

Acute respiratory infections are one of the prevalent pediatric diseases. Coinfections of respiratory viruses and atypical bacterial respiratory pathogens are common [1]. Coronavirus disease 2019 (COVID-19) is considered one of the most pathogens which targets the human respiratory system causing atypical pneumonia and severe acute respiratory syndrome (SARS) [2].

Numerous patients admitted to hospitals with pneumonia and SARS accompanied by rising deaths reported daily which overwhelms the health-care systems worldwide. Yet no specific treatment or vaccine has been developed for COVID-19 disease despite of high infectivity and rapid transmission, World Health Organization declared COVID-19 outbreak as global pandemic [3].

A constellation of Egyptian governmental restrictions has been released to control the spreading and transmission of the disease. Curfew, lockdown, and stay-at-home orders have been applied to support social distancing and separation [4].

COVID-19 pandemic quarantine and school closure have unfavorable effects on families especially children and adolescents. It is recognized that when children are off of school such as in weekend's vacations and summer breaks, they are physically less active, spend more screen time, have irregular pattern of sleep, and less healthy diets, resulting in excess weight gain, and loss of cardiorespiratory fitness [5].

Physical activity of children and adolescents is tightly adherent to school-related activities, active movement, and sport practicing [6]. In addition, stay-athome instructions reduce the opportunities for physical activity among children, particularly for those that living in urban areas or in small apartments [7].

Prolonged screen time is associated with experiencing overweight and obesity in childhood, which is more likely attributed to sedentary time and the association between screen time and frequent snacking [8]. 
Excess weight gained during the lockdown may not be easily reversible and might contribute to excess adiposity during adulthood [9].

Many challenging and stressor effects are facing children and adolescents that confined with prolonged home stay duration, inadequate information, lack of friends and classmates contact, absence of home personal space, fears of infection, frustration, and monotony, in addition to family financial burdens [10].

Breaking of daily activity caused by the curfew and lockdown could result in boredom and monotony [11]. Furthermore, continuous talking and hearing about the COVID-19 from media or family members can be stressful. Stress is leading attitude toward too much eating especially toward comfort food which contains excess sugar [12]. Comfort food contains sugar and simple carbohydrate increased serotonin release that helps in decrease stress and ameliorate mood and temper [13].

Home environment and child raising attitude are the most important factors that touch food behavior through joint interaction [14]. Parents may affect their children's eating behaviors, as they may habitually use food to control or regulate their children upset or negative emotions and the children acquired it as learnt behavior [15].

This study aimed at surveying changes in dietary pattern and related health factors in Egyptian children and adolescents in order to highlight the collateral hidden threats during the COVID-19 outbreak closure.

\section{Methods}

A cross-sectional questionnaire was conducted during the lockdown and curfew to survey the changes in dietary pattern, eating behavior, and physical activity in Egyptian children and adolescents. An electronic questionnaire designed through Google forms was distributed through social media sites to parents or caregivers targeting children and adolescents aged 4-16 years old of both sexes. It was started on the $12^{\text {th }}$ of May, 2020, after two whole months of governmental restrictions; school closure, community activity limitations, curfew, and quarantine measures, in addition to public health instructions and awareness of social distancing. The questionnaire was available online for 2 weeks.

Ethical approval was taken from the Medical Ethical Committee of the National Research Center. All respondents provided informed consent, which explained the aim of the study, the privacy policy, time consumed by the participant, and the benefits risk issues. The Parent/caregiver could only continue the questionnaire after agreement on participation.
This electronic questioner was designed to include:

- Sociodemographic data as age, gender, residence, father, and mother education level Information about regular activities before COVID-19 pandemic, following strict quarantine measures, and night sleeping hours after lockdown

- Eating habits changes which included questions about alteration in eating habits during the lockdown. It was reviewing change of appetite, change pattern of food types such as eating proteins, fruits and vegetables, and unhealthy food, and change of some eating habits such as more frequent snacking and late night meals. Beside determination if these changes were associated with the pandemic lockdown or not. Moreover, reporting the association between change of eating desire and specific mood condition such as boredom, frustration, or anger

- $\quad$ Screen time survey which includes questions about alteration in screen time and frequency of electronics usage.

After successful submitting, the parent/ caregiver receives an acknowledge note for participation and a link if he/or she would like to respond for another child.

All the data were converted automatically to Google sheets and inspected carefully from the team to exclude any error or mistaken data.

\section{Results}

The analytic sample of this study was 765 participants with age ranged between 4 and 16 years old. They are of matched sex groups. They are classified according to their age group into; 211 children were $<6$ years $(27.6 \%), 440$ children were $6-12$ years old $(57.5 \%)$, and 114 children were above 12 years old (14.9\%) (Table 1).

Most of their parents were highly educated as $735(96.1 \%)$ of the children's fathers and $739(96.6 \%)$ of the children's mothers were highly educated (Table 1).

Descriptive reviewing about change lifestyle and behavior revealed 505 children $(66.0 \%)$ followed strict quarantine measures; about 426 children $(55.7 \%)$ were performing physical activity before quarantine measures. Three hundred thirty-four children $(43.7 \%)$ were practicing for more than $3 \mathrm{~h} /$ week. About 354 children $(46.3 \%)$ showed number of night sleeping hours more than $6-8 \mathrm{~h}$ daily (Table 1 ).

The analytic data about change of eating patterns and habits showed that 243 children $(31.8 \%)$ 
have increased appetite after COVID-19 closure. About 349 children $(45.6 \%)$ have increased sweets and unhealthy food consumption after COVID-19 closure. On the other hand, 288 children (37.6\%) showed increased frequent snacking between meals after COVID-19 closure, and about 406 children (53.1\%) showed increase in late snacks during night after COVID-19 closure. These changes of eating patterns were clear in the 6-12 years age group. Moreover, 627 children $(82.0 \%)$ revealed that the change in eating behavior was usually associated with boring (Table 2).

Reviewing the data about effect of quarantine and lockdown on electronic and screen time usage showed that 724 children $(94.6 \%)$ have increased usage of electronics and screen time (Table 3).

Children and adolescence were exposed to different types of media consumption TV watching, mobile and tablets' screens, laptops, and videogame playing. Categorizing daily extra screen time exposure of our sample revealed that 483 children (63.1\%) used mobile screen time over 3 h/day, 417 children (54.5\%) used TV watching over $3 \mathrm{~h} /$ day, and 233 children $(30.5 \%)$ were playing video games more than $3 \mathrm{~h} /$ day, while only 124 children (16.2\%) were laptop users. That alongside of 434 children (56.7\%) shifted to home schooling and distant learning (Table 3).

Correlating analysis of changes of eating pattern and extra screen time usage during curfew and lockdown showed that significant positive correlation between increased appetite and mobile screen time, laptop screen time, and video gaming. Increased sweets and unhealthy food consumption was positively correlated with TV watching and mobile screen time. Our study also showed significant positive correlation between uncaring about eating fruits and vegetables and increase screen time for each of mobile, and laptop

Table 1: Socio-descriptive data of the studied sample

\begin{tabular}{|c|c|c|c|c|c|}
\hline Item $(n=765)$ & Category & Frequency & Percent & Chi-square & $p$-value \\
\hline \multirow[t]{2}{*}{ Sex } & Male & 408 & 53.3 & 3.400 & 0.065 \\
\hline & Female & 357 & 46.7 & & \\
\hline \multirow[t]{3}{*}{ Age stage } & $<6$ years & 211 & 27.6 & 219.773 & 0.000 \\
\hline & $6-12$ years & 440 & 57.5 & & \\
\hline & More than 12 years & 114 & 14.9 & & \\
\hline \multirow[t]{4}{*}{ Education stage } & Nursery & 229 & 29.9 & 422.425 & 0.000 \\
\hline & Primary & 407 & 53.2 & & \\
\hline & Preparatory & 83 & 10.8 & & \\
\hline & Secondary & 46 & 6.0 & & \\
\hline \multirow[t]{2}{*}{ Follow strict quarantine measures } & Yes & 505 & 66.0 & 913.844 & 0.000 \\
\hline & No & 260 & 34.0 & & \\
\hline \multirow[t]{2}{*}{ Father educational level } & Higher qualification & 735 & 96.1 & 910.624 & 0.000 \\
\hline & Secondary school & 30 & 3.9 & & \\
\hline \multirow[t]{2}{*}{ Mother educational level } & Higher qualification & 739 & 96.6 & 819.957 & 0.000 \\
\hline & Secondary school & 26 & 3.4 & & \\
\hline \multirow[t]{5}{*}{ Regular activities before lockdown } & No & 131 & 17.1 & 654.340 & 0.000 \\
\hline & Physical activity & 426 & 55.7 & & \\
\hline & Drawing and arts & 20 & 2.6 & & \\
\hline & Other activity & 79 & 10.3 & & \\
\hline & Several activities & 109 & 14.2 & & \\
\hline \multirow[t]{4}{*}{ Number of activity hours before lockdown } & $<3 \mathrm{~h} /$ week & 232 & 30.3 & 203.392 & 0.000 \\
\hline & More than $3 \mathrm{~h} /$ week & 334 & 43.7 & & \\
\hline & $<3 \mathrm{~h} /$ day & 96 & 12.5 & & \\
\hline & More than $3 \mathrm{~h} /$ day & 103 & 13.5 & & \\
\hline \multirow[t]{3}{*}{ Number of night sleeping hours after lockdown } & $<6 \mathrm{~h}$ & 178 & 23.3 & 63.584 & 0.000 \\
\hline & $6-8 \mathrm{~h}$ & 233 & 30.5 & & \\
\hline & More than $8 \mathrm{~h}$ & 354 & 46.3 & & \\
\hline
\end{tabular}

$p \leq 0.005$ (highly significant), $\leq 0.05$ (significant), $>0.05$ (insignificant).

Table 2: Change of eating pattern categorized by age group

\begin{tabular}{|c|c|c|c|c|c|c|c|c|c|}
\hline \multirow[t]{2}{*}{ Change in eating pattern } & \multirow[t]{2}{*}{ Category } & \multicolumn{3}{|c|}{ Age stage (\%) } & \multirow[t]{2}{*}{$\mathrm{F}$} & \multirow{2}{*}{$\begin{array}{l}\text { p one-way } \\
\text { ANOVA }\end{array}$} & \multicolumn{3}{|l|}{ Total } \\
\hline & & $<6$ years & $6-12$ years & More than 12 years & & & No $(\%)$ & Chi-square & $p$-value \\
\hline \multirow[t]{3}{*}{ Decrease or loss of appetite } & No & $87(41.2)$ & $259(58.9)$ & $72(63.2)$ & 9.484 & 0.000 & $418(54.6)$ & 185.953 & .000 \\
\hline & Preexisting before lockdown & 39 (18.5) & $57(13.0)$ & $16(14.0)$ & & & $112(14.6)$ & & \\
\hline & Occurred after lockdown & $85(40.3)$ & $124(28.1)$ & $26(22.8)$ & & & $235(30.7)$ & & \\
\hline \multirow[t]{3}{*}{ Increase of appetite } & No & $161(76.3)$ & $226(51.4)$ & $59(51.8)$ & 21.801 & .000 & $446(58.3)$ & 269.278 & .000 \\
\hline & Preexisting before lockdown & $18(8.5)$ & $49(11.1)$ & $9(7.9)$ & & & $76(9.9)$ & & \\
\hline & occurred after lockdown & $32(15.2)$ & $165(37.5)$ & $46(40.4)$ & & & $243(31.8)$ & & \\
\hline Increase sweets and & no & $59(28.0)$ & $137(31.1)$ & $44(38.6)$ & 2.037 & 0.131 & $240(31.4)$ & 60.008 & .000 \\
\hline \multirow[t]{2}{*}{ unhealthy food } & Preexisting before lockdown & $47(22.3)$ & $104(23.6)$ & 25 (21.9) & & & $17623.0)$ & & \\
\hline & occurred after lockdown & $105(49.8)$ & 199 (45.2) & $45(39.5)$ & & & $349(45.6$ & & \\
\hline Does not care about eating & No & $104(49.3)$ & $201(45.7)$ & $41(36.0)$ & .192 & 0.826 & $346(45.2)$ & 91.082 & .000 \\
\hline \multirow{2}{*}{ vegetables and fruits } & Preexisting before lockdown & $69(32.7)$ & $158(35.9)$ & $56(49.1)$ & & & $283(37.0)$ & & \\
\hline & Occurred after lockdown & $38(18.0)$ & $81(18.4)$ & 17 (14.9) & & & $136(17.8)$ & & \\
\hline Decrease in his regular protein & No & $76(36.0)$ & $170(38.6)$ & $42(36.8)$ & 192 & 0.826 & $288(37.6)$ & 52.306 & .000 \\
\hline \multirow{2}{*}{ intake } & Preexisting before lockdown & $78(37.0)$ & $190(43.2)$ & 47 (41.2) & & & $315(41.2)$ & & \\
\hline & Occurred after lockdown & $57(27.0)$ & $80(18.2)$ & $25(21.9)$ & & & $162(21.2)$ & & \\
\hline \multirow[t]{3}{*}{ Snacks between meals } & No & $69(32.7)$ & $136(30.9)$ & $38(33.3)$ & .446 & 0.640 & $243(31.8)$ & 6.565 & .000 \\
\hline & Preexisting before lockdown & 69 (32.7) & $135(30.7)$ & $30(26.3)$ & & & $234(30.6)$ & & \\
\hline & Occurred after lockdown & $73(34.6)$ & 169 (38.4) & $46(40.4)$ & & & $288(37.6)$ & & \\
\hline \multirow[t]{3}{*}{ Late snacks during night } & No & 79 (37.4) & $131(29.8)$ & $29(25.4)$ & 1.507 & 0.222 & $239(31.2)$ & 469.609 & .000 \\
\hline & Preexisting before lockdown & $28(13.3)$ & $67(15.2)$ & $24(21.1)$ & & & 119 (15.6) & & \\
\hline & Occurred after lockdown & $104(49.3)$ & $241(54.8)$ & 61 (53.5) & & & $406(53.1)$ & & \\
\hline & No change & $12(36.4)$ & $16(48.5)$ & $5(15.2)$ & 6.806 & 0.001 & $33(4.3)$ & 23.396 & .001 \\
\hline \multirow{3}{*}{ behavior } & With severe depression & $22(38.6)$ & $26(45.6)$ & $9(15.8)$ & & & $57(7.4)$ & & \\
\hline & With severe anger & 25 (52.1) & 19 (39.6) & $4(8.3)$ & & & $48(6.3)$ & & \\
\hline & With boring & $152(24.2)$ & $379(60.4)$ & $96(15.3)$ & & & $627(82.0)$ & & \\
\hline
\end{tabular}


Table 3: Lockdown effect on electronic screen time usage

\begin{tabular}{|c|c|c|c|c|c|}
\hline$n=765$ & Category & Frequency & Percent & Chi-square & p-value \\
\hline \multirow[t]{2}{*}{ Lockdown effect on electronics and screen use } & Yes & 724 & 94.6 & 609.790 & 0.000 \\
\hline & No & 41 & 5.4 & & \\
\hline \multirow[t]{3}{*}{ Mobile extra screen time } & No use & 104 & 13.6 & 316.525 & 0.000 \\
\hline & $<3 \mathrm{~h} /$ day & 178 & 23.3 & & \\
\hline & More than $3 \mathrm{~h} /$ day & 483 & 63.1 & & \\
\hline \multirow[t]{3}{*}{ TV extra screen time } & No use & 155 & 20.3 & 157.208 & 0.000 \\
\hline & $<3 \mathrm{~h} /$ day & 193 & 25.2 & & \\
\hline & More than $3 \mathrm{~h} /$ day & 417 & 54.5 & & \\
\hline \multirow[t]{3}{*}{ Laptop extra screen time } & No use & 519 & 67.8 & 409.984 & 0.000 \\
\hline & $<3 \mathrm{~h} /$ day & 122 & 15.9 & & \\
\hline & More than $3 \mathrm{~h} /$ day & 124 & 16.2 & & \\
\hline \multirow[t]{3}{*}{ Video game extra screen time } & No use & 426 & 55.7 & 203.631 & 0.000 \\
\hline & $<3 \mathrm{~h} /$ day & 106 & 13.9 & & \\
\hline & More than $3 \mathrm{~h} /$ day & 233 & 30.5 & & \\
\hline \multirow[t]{2}{*}{ Remote learning } & Yes & 434 & 56.7 & 13.868 & 0.000 \\
\hline & No & 331 & 43.3 & & \\
\hline
\end{tabular}

Table 4: Correlation between change of eating patterns and each of screen time and sleeping hours

\begin{tabular}{|c|c|c|c|c|c|c|}
\hline \multirow[t]{2}{*}{ Change of eating pattern $n=765$} & \multicolumn{5}{|c|}{ Electronic screen time usage } & \multirow{2}{*}{$\begin{array}{l}\text { No. of sleeping hours } \\
\text { after lockdown }\end{array}$} \\
\hline & Mobile extra screen time & TV extra screen time & $\begin{array}{l}\text { Laptop extra } \\
\text { screen time }\end{array}$ & $\begin{array}{l}\text { Video game extra } \\
\text { screen time }\end{array}$ & $\begin{array}{l}\text { Remote } \\
\text { learning }\end{array}$ & \\
\hline \multicolumn{7}{|l|}{ Decrease or loss of appetite } \\
\hline $\mathrm{r}$ & 0.012 & $0.072^{*}$ & $-0.139^{\star *}$ & -0.023 & $0.112^{\star *}$ & -0.044 \\
\hline $\mathrm{p}$ & 0.736 & 0.047 & 0.000 & 0.534 & 0.002 & 0.221 \\
\hline \multicolumn{7}{|l|}{ Increase of appetite } \\
\hline $\mathrm{r}$ & $0.125^{\star \star}$ & 0.043 & $0.162^{\star *}$ & $0.123^{* *}$ & -0.065 & 0.027 \\
\hline $\mathrm{p}$ & 0.001 & 0.234 & 0.000 & 0.001 & 0.073 & 0.460 \\
\hline \multicolumn{7}{|l|}{ Increase sweets and unhealthy food } \\
\hline $\mathrm{r}$ & $0.074^{*}$ & $0.114^{\star *}$ & 0.022 & 0.047 & 0.001 & $-0.076^{*}$ \\
\hline $\mathrm{p}$ & 0.041 & 0.002 & 0.551 & 0.196 & 0.979 & 0.036 \\
\hline \multicolumn{7}{|c|}{ Does not care about eating vegetables and fruits } \\
\hline r & $0.093^{*}$ & 0.024 & $0.102^{\star *}$ & 0.045 & $0.097^{\star *}$ & $-0.131^{* *}$ \\
\hline $\mathrm{p}$ & 0.010 & 0.503 & 0.005 & 0.214 & 0.007 & 0.000 \\
\hline \multicolumn{7}{|c|}{ Decrease in his regular protein intake } \\
\hline $\mathrm{r}$ & $0.106^{\star *}$ & 0.047 & 0.015 & 0.031 & $0.075^{\star}$ & $-0.139^{\star *}$ \\
\hline $\mathrm{p}$ & 0.003 & 0.197 & 0.673 & 0.396 & 0.038 & 0.000 \\
\hline \multicolumn{7}{|l|}{ Frequent snacks between meals } \\
\hline$r$ & 0.059 & $0.076^{\star}$ & $0.198^{\star *}$ & 0.065 & $-0.083^{*}$ & -0.003 \\
\hline $\mathrm{p}$ & 0.104 & 0.035 & 0.000 & 0.071 & 0.022 & 0.942 \\
\hline \multicolumn{7}{|l|}{ Late snacks during night } \\
\hline $\mathrm{r}$ & $0.158^{\star *}$ & $0.090^{*}$ & 0.069 & $0.087^{\star}$ & 0.041 & -0.032 \\
\hline $\mathrm{p}$ & 0.000 & 0.013 & 0.058 & 0.016 & 0.262 & 0.381 \\
\hline
\end{tabular}

and remote learning. Furthermore, there was positive correlation between decreased protein serving intake and each of mobile screen time and remote learning (Table 4).

TV watching and laptop screen time were positively significantly associated with frequent snacking between meals. However, remote learning was inversely related to frequent snacking between meals (Table 4).

Mobile screen time, TV screen time, and video gaming were significantly positively correlated with late night snacking (Table 4).

This study noted significant negative correlation between night sleeping hours and increased sweet and unhealthy food ingestion and carelessness of eating fruits and vegetables and protein serving intake; less night sleeping hours is related to more sweet and unhealthy food ingestion, more increase in the carelessness of receiving fruits and vegetables and protein servings (Table 4).

Linear stepwise regression analysis of change of eating patterns revealed association between increased appetite and increase each of age stage group, mobile screen time and TV screen time (Table 5).

Regression analysis of predicting factors for frequent snacking between meals denoted significant
Table 5: Linear stepwise regression analysis of predicting factors for increase of appetite

\begin{tabular}{|c|c|c|c|c|c|}
\hline \multirow[t]{2}{*}{ Predicting factors } & \multicolumn{2}{|c|}{$\begin{array}{l}\text { Unstandardized } \\
\text { coefficients }\end{array}$} & \multirow{2}{*}{$\begin{array}{l}\text { Standardized } \\
\text { coefficients } \\
\text { Beta }\end{array}$} & \multirow[t]{2}{*}{$t$} & \multirow[t]{2}{*}{ Sig. } \\
\hline & $\bar{B}$ & Std. Error & & & \\
\hline (Constant) & 0.053 & 0.172 & & 0.308 & 0.758 \\
\hline Age stage & 0.401 & 0.077 & 0.189 & 5.232 & 0.000 \\
\hline Laptop extra screen time & 0.150 & 0.044 & 0.121 & 3.375 & 0.001 \\
\hline TV extra screen time & 0.080 & 0.038 & 0.074 & 2.093 & 0.037 \\
\hline
\end{tabular}

Table 6: Linear stepwise regression analysis of predicting factors for frequent snacking between meals

\begin{tabular}{|c|c|c|c|c|c|}
\hline \multirow[t]{2}{*}{ Predicting factors } & \multicolumn{2}{|c|}{$\begin{array}{l}\text { Unstandardized } \\
\text { coefficients }\end{array}$} & \multirow{2}{*}{$\begin{array}{l}\text { Standardized } \\
\text { coefficients } \\
\text { Beta }\end{array}$} & \multirow[t]{2}{*}{$\mathrm{t}$} & \multirow[t]{2}{*}{ Sig. } \\
\hline & $\mathrm{B}$ & Std. Error & & & \\
\hline (Constant) & 1.151 & 0.086 & & 13.359 & 0.000 \\
\hline Laptop extra screen time & 0.209 & 0.041 & 0.179 & 5.036 & 0.000 \\
\hline TV extra screen time & 0.079 & 0.036 & 0.078 & 2.201 & 0.028 \\
\hline
\end{tabular}

association with increased laptop screen time and TV screen time (Table 6).

Late night snacking was significantly associated with increased mobile screen time, TV screen time, and video gaming (Table 7).

\section{Statistical analysis}

Data were collected, verified, coded, and analyzed using the Statistical Package for the Social 
Table 7: Linear stepwise regression analysis of predicting factors for late night snacking

\begin{tabular}{|c|c|c|c|c|c|}
\hline \multirow[t]{2}{*}{ Predicting factors } & \multicolumn{2}{|c|}{$\begin{array}{l}\text { Unstandardized } \\
\text { coefficients }\end{array}$} & \multirow{2}{*}{$\begin{array}{l}\text { Standardized } \\
\text { coefficients } \\
\text { Beta }\end{array}$} & \multirow[t]{2}{*}{$\mathrm{t}$} & \multirow[t]{2}{*}{ Sig. } \\
\hline & $\mathrm{B}$ & Std. Error & & & \\
\hline (Constant) & 1.174 & 0.123 & & 9.506 & 0.000 \\
\hline Mobile extra screen time & 0.178 & 0.041 & 0.154 & 4.310 & 0.000 \\
\hline TV extra screen time & 0.105 & 0.039 & 0.097 & 2.714 & 0.007 \\
\hline Video game extra screen time & 0.072 & 0.033 & 0.079 & 2.178 & 0.030 \\
\hline
\end{tabular}

Science (SPSS) version 26 (SSPS Inc., Pennsylvania, USA). Qualitative data presented as number and percentages. The comparison between two groups with qualitative data was done by using Chi-square test. Spearman's test correlation analysis was used to assess the relationship between two ordinal parameters in the same group. All tests were two-tailed, with a significance level of $p \leq 0.05$ and highly significance at $p$ $\leq 0.005$. Linear stepwise regression analysis was used to detect the predictors of the dietary change variable.

\section{Discussion}

Lockdown and school closure created large domestic leisure time; nevertheless, children have not been allowed to use regular playgrounds, prevented from social group activities and sports clubs, strict implication for social distancing, and limited contact to peers [16].

Our findings suggest that with respect to 2 months of quarantine and curfew measures a constellation of collateral eating pattern changes and their related hazardous alterations in children and adolescents life style. About $66 \%$ of our studied group was following strict quarantine and lockdown measures which mean long staying at home, more exposure to life style alterations such as less physical activity, more usage of electronics, long screen time exposure, and unhealthy change of the food patterns and eating behaviors.

As reviewing the dietary and eating patterns of our participants under COVID-19 lockdown, the main noticed dietary pattern changes were increased appetite $(31.8 \%)$, increased sweets and unhealthy food consumption (45.6\%), frequent snacking between meals (37.6\%), and increased late night snacks (53.1\%). These poor eating patterns seemed to be adherent to each other as frequent snacking between meals and late night snacks need easily available rapid food such as sweet and most of unhealthy food types in presence of increased appetite.

The main age group showed eating patterns affection was children aged 6-12 years old, which may be explained by that this age group can be obligated and forced to follow the strict quarantine measures and stay at home orders. However, to some extent, they are self-dependable and can prepare easy rapid snacks alone and frequent snacking between meals without help.

Besides, school environments offer schedule and routine about mealtimes, physical activity, and sleep time. These three crucial lifestyle aspects are implicated in obesity risk [17]. Hence, school closure related to COVID-19 pandemic distributed this routine and omitted this privilege.

An online trans-continental survey done to determine the effect of COVID-19 pandemic confinements on multiple life style behaviors reviewed a negative effect on all grades physical activity even walking, poor eating patterns included frequent snacking, increased late night snacking, increased numbers of main meals, eating out of control, and high unhealthy food consumption [18].

In favor to our study, an Italian public survey study about change in dietary habits during COVID-19 lockdown reported that an increase in comfort unhealthy food consumption (sweets, desert, and salty snacks), in addition this increase was attributed to psychological state of anxiety toward pandemic [19].

Another Italian survey reported third the studied sample eat less healthy food (fruit, vegetables, nuts, and legumes). Alongside body mass index was positively associated to the increased appetite and junk food consumption while less age was directly associated to night snacks and junk food consumption [20].

Moreover, an experience dietary study from Poland during COVID-19 lockdown revealed more eating and frequent snacking during pandemic quarantine. Notably, increased weight was related with reduced consumption of vegetables, fruit, and legumes during quarantine, and frequent providing of meat, dairy, and fast-foods [21].

Paralleling a collaborative multinational study involved Spain, Italy, Brazil, Colombia, and Chile compared average food intake before and during COVID-19 lockdown in children and adolescents 10-19 years old reported significant increase in fried and sweet food average intakes during COVID-19 lockdown comparing to that before pandemic lockdown [22].

The majority of our participants $82.0 \%$ noted associative change in eating behavior with boring. Boredom is a distinct individual feeling perceived due to lack of meaning and dissatisfaction in the present life state, circumstances, and actions [23].

Eating is poor coping mechanism to reduce the intensity of different negative stressors associated with pandemic, school closure, and lockdown [24]. Foods preferred and usually consumed in response to negative emotions are commonly rich in sugar and/or fat. These foods are palatable delivering hedonic pleasure and immediate instant reward that may distract from the experience of negative emotions [25]. However, 
overeating in children and adolescents is expressed by an eating behavior associated with frequent snacking, eating high energy-dense foods greater total caloric intake, and overweight [15].

Our findings were supported by a large consecutive sequential study done by Moynihan et al. at 2015 [11] about the relationship between boredom and eating behavior changes, it showed that boredom state predicted more calorie and food nutrients consumption. In addition, it increased the desire for snacking with preference of unhealthy food intake to escape the individual awareness with state of boredom.

The notable increase in sweets and unhealthy food consumption in our study may be explained by the resulting release of serotonin and tryptophan hormones that related to elevated mood which may improve the adverse feeling of boredom [13]. Meanwhile, these types of food are accessible and almost ready to prepare. On the other hand, increased frequent snacking between meals and late night snacking may be attributed to prolonged screen time and delayed sleeping time.

Saunders et al. [26] reported several foods types in the unhealthy diet such as fast foods, ice cream, fried food, French fries, potato chips, cakes, and sugar-sweetened sodas that are ready to eat and are easily available.

In this study, $55.7 \%$ were performing physical activity before quarantine measures. Furthermore, $43.7 \%$ were practicing for more than $3 \mathrm{~h} /$ week. Physical activity of children and adolescents is tightly adherent to school-related activities, active movement, and sport practicing [6]. Unfortunately, COVID-19 confinements were included schools, clubs, playgrounds, and gyms closure, prevented children from outdoor physical activity.

Sedentariness and inactivity are directly playing a role in many health outcomes such as obesity, metabolic syndrome, and cardiovascular diseases. Screen time, including watching television and playing electronic games, is considered as alternative indicators of Inactivity.

Digital electronic media usage represents fundamental part in children and adolescents lives, continuous rise of digital media leads to rise of time adherence and screen stickiness usage [27]. Besides, the benefits related to rapid access to information and rapid mass communication, screen exposure cause many health and psychological problems among children and adolescents [28].

This study reported $94.6 \%$ have increased usage of electronics and screen time after pandemic lockdown. About $63.1 \%$ had mobile screen time over $3 \mathrm{~h} /$ day, $54.5 \%$ were TV watching over $3 \mathrm{~h} /$ day, and $30.5 \%$ were playing video games more than $3 \mathrm{~h} /$ day, while only $16.2 \%$ were laptop users. That alongside $56.7 \%$ shifted to home schooling and electronic distant learning.
Our study suggested highly significant positive correlation between increased appetite and mobile screen time, laptop screen time, and video gaming ( $p \leq 0.005$ ). Increased sweets and unhealthy food consumption were significant positively correlated with TV watching $(p \leq 0.05)$ and mobile screen time ( $p \leq 0.005$ ). Our study also showed high significant positive correlation between uncaring about eating fruits and vegetables and increase screen time for each of mobile, and laptop and remote learning ( $p \leq 0.005)$. Furthermore, there was positive correlation between decreased protein serving intake and each of mobile screen time $(p \leq 0.005)$ and remote learning $(p \leq 0.05)$.

TV watching and laptop screen time were positively significantly associated with frequent snacking between meals ( $p \leq 0.05)$ and ( $p \leq 0.005$ ), respectively. However, remote learning was inversely related to frequent snacking between meals ( $p \leq 0.05)$.

Mobile screen time, TV screen time, and video gaming were positively significantly correlated with late night snacking $(p \leq 0.005, \leq 0.05$, and $\leq 0.05$, respectively).

The relationship between electronic screen time and change of eating patterns was backboned by linear stepwise regression analysis showed: Age stage group, increased laptop screen time, and increased TV screen time were significantly associated with increased appetite ( $p \leq 0.005, \leq 0.005$, and $\leq 0.05$, respectively). Increased laptop screen time and TV screen time were significantly associated with frequent snacking between meals ( $p \leq 0.005)$ and ( $p \leq 0.05)$, respectively. Increased mobile screen time, TV screen time, and video gaming were significantly associated with late night snacking ( $p \leq 0.005, \leq 0.005$, and $\leq 0.05$, respectively).

This agrees with other studies, children who watch TV during two or more meals per day receive less portions of healthy food, more processed meat, and extra junk food than children who prevented from watching TV during mealtimes or only allowed for one meal per day [29], [30], [31].

Ruiz-Roso et al. [22] study done during COVID-19 lockdown 2020 elucidated TV watching during mealtimes is associated to fewer intakes of vegetables and fruits during the COVID-19 lockdown and a higher fried food, sweet food, and sugar sweetened beverages consumption in children and adolescents aged 10-19 years.

Enlarged screen time usage in childhood is considered a contributing risk factor for obesity and delayed development of the child which is intensely associated with decrease outdoor activity and increase body mass index and overweight [32].

Many studies have been denoted similar results, in a study done on children aged 10-12, there was a direct relationship between inactivity and overweight. Consuming more screen time on TV watching, mobile using, and video gaming was greater risk for obesity and overweight [33]. 
Jalo et al. [34] carried out an international study at 2019, which involved 12 sites representing different cultural and environmental aspects that revealed positive association between behavioral eating and an unhealthy diet pattern, moderate physical activity, and TV viewing.

Lockdown and stay at home commands have increased consumption of electronic entertainment especially online gaming; excessive gaming has negative influences including harm to mental health, sleep patterns, or physical health [35].

The present study revealed significant negative correlation between night sleeping hours and increased sweets and unhealthy food ingestion $(p \leq 0.05)$ and carelessness of eating fruits and vegetables and protein serving intake $(p \leq 0.005)$ that means less night sleeping hours is correlated to more sweet and unhealthy food ingestion, more increase in the carelessness of receiving fruits and vegetables and protein servings.

Deficient sleep and reduced sleep time is a strong risk factor for obesity in children. Cross-sectional studies have indicated that late sleeping time increases the possibility of obesity [36].

These poor related vicious circus that started with lockdown confinements, stay at home, decreased physical activity, prolonged screen time, late sleeping time, then consequentially unhealthy food patterns, and eating habits.

\section{Conclusion}

COVID-19 pandemic has more threats that cross beyond those of direct viral infection that unfavorably affect children and adolescences. Prolonged lock down and home confinement leads to change of eating pattern and poor eating habits that associated with reduced physical activity and prolonged screen time. These are contributing factors causing excess weight gain and increased adiposity health risks later in life. Revising our requirements and resources regarding such overwhelming cries are a must. Allowing cooperative network and plan to face quarantine and lockdown physical health impacts affect children and adolescents.

\section{Recommendations}

This quick surveying study provides the privilege of focusing on management of poor dietary patterns and eating habits, and their related hazardous alterations of children and adolescent's lifestyle during pandemic lockdown. Here, some insights and recommendations that may help in managing the problem:
Eating well-balanced meals, having adequate servings, sticking to home-cooked food, avoid irregular snacking, and keeping shared family mealtimes.

Practice indoor activity breaks (such as stretch breaks or dance breaks). Provide physical education sessions either in the contexts of school schedule or media programs.

Receiving adequate night sleeping, schedule suitable time for night going to sleep and morning waking up.

Teach children that media has a beginning and an end; watching is not an all day mission.

Create schedule for online and offline times, let children sharing in setting limits on their screen usage, create a space for family gathering, talking, playing games, and reading books.

Watch out the media content to outfit the child age. Provide creative exciting content for the screen time such as touring the sights of our country or other countries handling wonders and curiosities around the world. Co-watching or watching together is effective.

Allow them contact their friends, relatives, and family members through phone or video chats.

\section{Limitations of the study}

This study facing several limitations; there is limited available resources and time-sensitivity of the COVID-19 pandemic, the strategy of snowball sampling was accepted which was not based on a random sample selection so the study could not reflect the real exact pattern of general population, besides biased results as the number of participants do not reflect the society.

This study was limited to availability of internet and social media activity usage. Subjective evaluation and self-reported levels, as no availability of face to face interaction by physical health professionals due to distancing circumstances and pandemic emergency state. Similarly, respondents might have provided socially desirable responses in terms of the satisfaction with the health information received and precautionary measures.

Another limitation is the evaluating scale has to be modified and shortened to encourage participation and avoid fidgets and quit the questioner so, it became less informative. Lastly, no supportive data about before lockdown dietary patterns was available to help in more comparative analysis.

\section{Acknowledgment}

All thanks and appreciation to National Research Centre affiliation, and all participants agreed to share in this electronic questionaire. 


\section{References}

1. Baroudy NR, Refay AS, Hamid TA, Hassan DM, Soliman MS, Sherif L. Respiratory viruses and atypical bacteria co-infection in children with acute respiratory infection. Open Access Maced J Med Sci. 2018;6(9):1588-93. https://doi.org/10.3889/ oamjms.2018.332y

2. Wang C, Pan R, Wan X, Tan Y, Xu L, Ho CS, et al. Immediate psychological responses and associated factors during the initial stage of the 2019 coronavirus disease (COVID-19) epidemic among the general population in China. Int $\mathrm{J}$ Environ Res Public Health. 2020;17(5):1729. https://doi.org/10.3390/ ijerph17051729

PMid:32155789

3. Galanakis CM. The food systems in the era of the coronavirus (COVID-19) pandemic crisis. Foods. 2020;9(4):523. https://doi. org/10.3390/foods 9040523

PMid:32331259

4. Lippi G, Henry BM, Bovo C, Sanchis-Gomar F. Health risks and potential remedies during prolonged lockdowns for coronavirus disease 2019 (COVID-19). Diagnosis. 2020;7(2):85-90. https:// doi.org/10.1515/dx-2020-0041

PMid:32267243

5. Wang G, Zhang J, Lam SP, Li SX, Jiang Y, Sun W, et al. Tenyear secular trends in sleep/wake patterns in Shanghai and Hong Kong school-aged children: A tale of two cities. J Clin Sleep Med. 2019;15(10):1495-502. https://doi.org/10.5664/ jcsm.7984

PMid:31596215

6. Hoffmann B, Kobel S, Wartha O, Kettner S, Dreyhaupt J, Steinacker JM. High sedentary time in children is not only due to screen media use: A cross-sectional study. BMC Pediatr. 2019;19(1):154. https://doi.org/10.1186/s12887-019-1521-8 PMid:31096946

7. Rundle AG, Park Y, Herbstman JB, Kinsey EW, Wang YC. COVID-19-related school closings and risk of weight gain among children. Obesity (Silver Spring). 2020;28(6):1008-9. https://doi.org/10.1002/oby.22813

PMid:32227671

8. Marsh S, Ni Mhurchu C, Maddison R. The non-advertising effects of screen-based sedentary activities on acute eating behaviours in children, adolescents, and young adults. A systematic review. Appetite. 2013;71:259-73. https://doi. org/10.1016/j.appet.2013.08.017

PMid:24001394

9. Pietrobelli A, Pecoraro L, Ferruzzi A, Heo M, Faith M, Zoller T, et al. Effects of COVID-19 lockdown on lifestyle behaviors in children with obesity living in Verona, Italy: A longitudinal study. Obesity. 2020;28(8):1382-5. https://doi.org/10.1002/oby.22861 PMid:32352652

10. Brooks SK, Webster RK, Smith LE, Woodland L, Wessely S, Greenberg N, et al. The psychological impact of quarantine and how to reduce it: rapid review of the evidence. Lancet. 2020;395(10227):912-20. https://doi.org/10.31219/osf.io/c5pz8

11. Moynihan AB, van Tilburg WA, Igou ER, Wisman A, Donnelly AE, Mulcaire JB. Eaten up by boredom: Consuming food to escape awareness of the bored self. Front Psychol. 2015;6:369. https:// doi.org/10.3389/fpsyg.2015.00369 PMid:25883579

12. Rodríguez-Martín BC, Meule A. Food craving: new contributions on its assessment, moderators, and consequences. Front Psychol. 2015;6:21. https://doi.org/10.3389/fpsyg.2015.00021 PMid:25657636

13. Ma Y, Ratnasabapathy R, Gardiner J. Carbohydrate craving: Not everything is sweet. Curr Opin Clin Nutr Metab Care. 2017;20(4):261-5. https://doi.org/10.1097/ mco.0000000000000374 PMid:28375878

14. Vaughn AE, Ward DS, Fisher JO, Faith MS, Hughes SO, Kremers SP, Musher-Eizenman DR, et al. Fundamental constructs in food parenting practices: A content map to guide future research. Nutr Rev. 2016;74(2):98-117. https://doi. org/10.1093/nutrit/nuv061

PMid:26724487

15. Steinsbekk S, Barker ED, Llewellyn C, Fildes A, Wichstrom L. Emotional feeding and emotional eating: Reciprocal processes and the influence of negative affectivity. Child Dev. 2018;89(4):1234-46. https://doi.org/10.1111/cdev.12756 PMid:28439888

16. Fegert JM, Vitiello B, Plener PL, Clemens V. Challenges and burden of the Coronavirus 2019 (COVID-19) pandemic for child and adolescent mental health: a narrative review to highlight clinical and research needs in the acute phase and the long return to normality. Child Adolesc Psychiatry Ment Health. 2020;14:20. https://doi.org/10.1186/s13034-020-00329-3 PMid:32419840

17. von Hippel PT, Workman J. From kindergarten through second grade, U.S. Children's obesity prevalence grows only during summer vacations. Obesity (Silver Spring). 2016;24(11):2296300. https://doi.org/10.1002/oby.21613

PMid:27804271

18. Ammar A, Brach M, Trabelsi K, Chtourou H, Boukhris $\mathrm{O}$, Masmoudi L, et al. Effects of COVID-19 home confinement on eating behavior and physical activity: Results of the ECLB-COVID19 international online survey. Nutrients. 2020;12(6):E1583. https://doi.org/10.37473/ dac/10.1101/2020.05.04.20072447 PMid:32481594

19. Scarmozzino F, Visioli F. Covid-19 and the subsequent lockdown modified dietary habits of almost half the population in an Italian sample. Foods. 2020;9(5):675. https://doi.org/10.3390/ foods 9050675

PMid:32466106

20. Di Renzo L, Gualtieri P, Pivari F, Soldati L, Attinà A, Cinelli G, et al. Eating habits and lifestyle changes during COVID-19 lockdown: An Italian survey. J Transl Med. 2020;18(1):229. https://doi.org/10.1186/s12967-020-02399-5 PMid:32513197

21. Sidor A, Rzymski P. Dietary choices and habits during COVID-19 Lockdown: experience from Poland. Nutrients. 2020;12(6):E1657. https://doi.org/10.3390/nu12061657 PMid:32503173

22. Ruiz-Roso MB, de Carvalho Padilha P, Mantilla-Escalante DC, Ulloa N, Brun P, Acevedo-Correa D, et al. Covid-19 confinement and changes of adolescent's dietary trends in Italy, Spain, Chile, Colombia and Brazil. Nutrients. 2020;12(6):E1807. https://doi. org/10.3390/nu12061807 PMid:32560550

23. Van Tilburg WA, Igou ER. On boredom: Lack of challenge and meaning as distinct boredom experiences. Motiv Emot. 2012;36:181-94. https://doi.org/10.1007/s11031-011-9234-9

24. Van Strien T. Causes of emotional eating and matched treatment of obesity. Curr Diab Rep. 2018;18(6):35. https://doi. org/10.1007/s11892-018-1000-x

PMid:29696418

25. Macht M. How emotions affect eating: A five-way model. Appetite. 2008;50(1):1-11. https://doi.org/10.1016/j.appet.2007.07.002 PMid: 17707947 
26. Elfhag K, Tholin S, Rasmussen F. Consumption of fruit, vegetables, sweets and soft drinks are associated with psychological dimensions of eating behaviour in parents and their 12-year-old children. Public Health Nutr. 2008;11(9):91423. https://doi.org/10.1017/s1368980008002371 PMid: 18498675

27. Lemola S, Perkinson-Gloor N, Brand S, Dewald-Kaufmann JF, Grob A. Adolescents' electronic media use at night, sleep disturbance, and depressive symptomsin the smartphone age. J Youth Adolesc. 2015;44(2):405-18. https://doi.org/10.1007/ s10964-014-0176-x PMid:25204836

28. Falbe J, Davison KK, Franckle RL, Ganter C, Gortmaker SL, Smith L, et al. Sleep duration, restfulness, and screens in the sleep environment. Pediatrics. 2015;135(2):e368-75. https://doi. org/10.1542/peds.2014-2306 PMid:25560435

29. Lissner L, Lanfer A, Gwozdz W, Olafsdottir S, Eiben G, Moreno LA, et al. Television habits in relation to overweight, diet and taste preferences in European children: The IDEFICS study. Eur J Epidemiol. 2012;27(9):705-15. https://doi.org/10.1007/ s10654-012-9718-2 PMid:22911022

30. Fulkerson JA, Loth K, Bruening M, Berge J, Eisenberg ME, Neumark-Sztainer D. Time 2 tlk 2nite: Use of electronic media by adolescents during family meals and associations with demographic characteristics, family characteristics, and foods served. J Acad Nutr Diet. 2014;114(7):1053-8. https://doi. org/10.1016/j.jand.2013.10.015

PMid:24361006

31. Robinson TN, Banda JA, Hale L, Lu AS, Fleming-Milici F, Calvert SL, et al. Screen media exposure and obesity in children and adolescents. Pediatrics. 2017;140(2):S97-101. https://doi. org/10.1542/peds.2016-1758k

PMid:29093041

32. Schwarzfischer P, Gruszfeld D, Socha P, Luque V, ClosaMonasterolo R, Rousseaux D, et al. Effects of screen time and playing outside on anthropometric measures in preschool aged children. PLoS One. 2020;15(3):e0229708. https://doi. org/10.1371/journal.pone.0229708

PMid:32119714

33. Moradi G, Mostafavi F, Azadi N, Esmaeilnasab N, Nouri B. Evaluation of screen time activities and their relationship with physical activity, overweight and socioeconomic status in children 10-12 years of age in Sanandaj, Iran: A cross-sectional study in 2015. Med J Islam Repub Iran. 2016;30:448. https://doi. org/10.4103/ijpvm.ijpvm_222_17 PMid:28210613

34. Jalo $E$, Konttinen $H$, Vepsäläinen $H$, Chaput J, Hu G, Maher C, et al. Emotional eating, health behaviours, and obesity in children: A 12-country cross-sectional study. Nutrients. 2019;11(2):351. https://doi.org/10.3390/nu11020351 PMid:30736444

35. Saunders JB, Hao W, Long J, King DL, Mann K, Fauth-Buhler M. Gaming disorder: Its delineation as an important condition for diagnosis, management, and prevention. J Behav Addict. 2017;6:271-9. https://doi.org/10.1556/2006.6.2017.039 PMid:28816494

36. Roy M, Haszard JJ, Savage JS, Yolton K, Beebe DW, Xu Y, et al. Bedtime, body mass index and obesity risk in preschoolaged children. Pediatr Obes. 2020;15(9):e12650. http://doi. org/10.1111/ijpo.12650.

PMid:32372572. 